\title{
THE INFLUENCE OF THE INTEGRATION IN THE EUROPEAN UNION ON THE ROMANIAN FISCAL LEGISLATION
}

\author{
Muntean Mircea, Associate Professor, PhD \\ UNIVERSITY OF BACAU \\ Păcurari Doina, Assistant \\ UNIVERSITY OF BACAU
}

\begin{abstract}
:
Fiscal policy constitutes - within the state's economic policy - a system by means of which the taxes and duties owed to the country's consolidated budget are established and collected. Taking into account the role fiscal policy has been playing since Romania's admission in the European Union, one of the goals ceaselessly looked for is its adapting to the international community's acquis through the implementation of the European directives in our context. The EU directives make reference to direct taxes: dividend tax, interest income tax, assets transfer, shares exchange, income taxation for the non-residents, and so on, along with the indirect taxes: valueadded tax, excise duties, etc. The paper approaches the main provisions within the contents of the European directives as well as the means of their implementation in the Romanian fiscal legislation regarding various types of taxes. The implementation of the European directives has been simultaneous with the establishing of measures concerning fiscal fraud prevention, frauds liable to have a negative impact on the state's consolidated budget.
\end{abstract}

Fiscal policy constitutes - within the state's economic policy - a system by means of which the duties and the taxes owed to the country's consolidated budget are established and collected.

Roughly speaking, both theoretically and practically, fiscal policy represents the system of principles, rules and norms concerned with: the contributors situation and administration, the evaluation, recording and redemption of debts, complaints checking and solving, specific assistance to the tax-payers so as to enable them to acquire knowledge about and to appropriately make use of fiscal legislation.

Considering the role of the fiscality, once Romania entered the European Union, its putting up with the community's acquis has become a steady pursuit.

The community's acquis consists of the body of laws, rights and liabilities common to all EU member-states, is meant to match this territory' $\mathrm{s}$ conditions, and refers to:

- the contents, principles and political goals of treaties;

- the legislation required in order to put them into practice and the Law Court's jurisprudence;
- the statements and resolutions adopted by the European Union;

- the measures - mutually accepted regarding both the external and the security policy;

- the measures concerning the judicial and home affairs systems;

- the international agreements the community concludes with the member states as far as the EU's fields is concerned.

The transposition of the community's acquis in Romania affected both the direct taxes and the indirect taxes.

The direct taxation refers to the fiscal policy on the profit tax, particularly to the fiscal policy on the dividends coming from the EU's member-states and the common fiscal policy on the mergers, the divisions, the partial divisions, the assets transfers and the shares exchanges between companies belonging to different EU's member-states.

In keeping with the Directive no. 90/435/CEE and the article 20, paragraph 1, letter a)., stipulated in the Fiscal Code, the dividends received by a Romanian legal entity - the parent-company - from one of its subsidiares located in some other memberstate are tax-free provided that it pays the 
profit tax with no exception and no other option and possesses at least $15 \%$ out of the registered share capital of a legal entity in any member-state, and at least $10 \%$ respectively, beginning on the $1^{\text {st }}$ of January 2009 , and, by the time the dividends are recorded, it has held that minimal share for over 2 years. The same conditions are required for the dividends got by the Romanian legal entity by means of its permanent establishment (situated in a member-state) to be free of tax.

The provisions mentioned in the Directive 90/435/CEE can also be applied to the dividends received all over Romania by the permanent establishments belonging to foreign legal entities from member-states the parent-companies - in their turn distributed by subsidiaries located in other member-states, so long as the foreign legal body gradually answers conditions stipulated by the article 20, paragraph 1 , letter a). from the Fiscal Code, such as: its setting up corresponds to the law available in the specific EU member-state; it is considered a resident of that particular member-state, and its establishment, according to a treaty for avoid duble taxation struck with some third party, is consequently not excluded from the EU region; it pays profit-tax or some similar tax to a member-state with no exception or other option; it owns at least $15 \%$ from the share capital of the subsidiary located in a member-state, $10 \%$ respectively, beginning on the $1^{\text {st }}$ of January 2009, capital held for over 2 years by the time the permanent office in Romania records the dividends.

In accordance with the provisions stipulated by the Directive no. 90/434/CEE, article 27, paragraph 1, in the Fiscal Code, it is established the mutual fiscal policy to be applied to the mergers, the divisions, the partial divisions, the assets transfers and the shares exchanges between companies belonging to different EU's member-states.

Companies of member-states are said to entertain general partnership providing they are gradually coping with the following conditions:

- they are constituted according to the law valid in the specific EU member-state;

- they pay the profit tax or a similar tax with no exception and no other option;
- they have the office in a member-state and, on the grounds of the treaty - signed with a third party - concerning the double-taxation avoidance, they are not considered outside the EU.

The Directive no. 90/434/CEE stipulates that the mergers and the divisions do not constitute assessable transfers for the difference between the market price of the transferred assets and liabilities and their ratable value. These directives are valid on condition that the beneficiary companies record the depreciation and any profit or loss concerning the above-mentioned assets and liabilities according to the provisions supposed to have been applied to the assigning company unless the merging, the division or the partial division had occurred.

As for the provisions or the reserves previously deduced from the taxable base by the contributing companies, without coming from the permanent offices abroad, the provisions of the directive in question indicate that these very commissions or reserves could be taken over, within the same deduction limits, by the beneficiary permanent office in Romania, the latter thus assuming the rights and the obligations of the assignors. The fiscal loss is not to be recovered by the permanent office of the beneficiary company located in Romania as far as the mergers, divisions, partial divisions, assets transfers and shares exchanges involving companies of two or more member-states are concerned.

According to the conditions imposed by the Directive no. 90/434/CEE, the beneficiary company's incomes, deriving from the revocation of its share in the subsidiary companies' capital, are taxation-free only if its share exceeds a rate of $15 \%, 10 \%$ respectively, with the $1^{\text {st }}$ of January 2009 .

With regard to the shares exchange, the provisions of the Directive no. 90/434/CEE states that, for mergers, divisions or share exchanges, the share-certificate allotment - staying for the beneficiary or acquiring company's capital - to some assignors' or acquisitions' member, in exchange for share-certificates representing the value of this company's capital, does not mean assessable transfers. 
This free-taxation is available providing that the share-holder does not supply the acquired share-certificates with a value higher than the one they had before events such as mergers, divisions or share exchanges had happened.

This free-taxation category excludes the allotment - having as its object the partial divisions - of the assignor's share-certificates, that are making the interest of the beneficiary's capital, unless the latter gives them a value higher than the one it used to have when it was taken over. If, later, the share certificates are transferred, the revenues or the income acquired are subjected to taxation, in accordance with the conditions imposed by the fiscal legislation.

Similarly, the provisions of the Directive no. 90/434/CEE, amended by the Directive 2005/19/CE, are applied to the shares transfer.

The mutual fiscal policy stipulated in the Directive no. 90/434/CEE and amended by the Directive 2005/19/CE, liable to be applied to mergers, divisions, partial divisions, assets transfers and shares exchanges between companies belonging to different EU member-states, are not valid in case of the particular actions whose purpose is fraud, tax evasion or lack of employees' representation in the administrative board of the company as the community's norms ask.

Enforcement of the Directive 90/434/CE leads to fiscal advantages through:

- the postponement of the additional value assessment;

- the possibility of taking over the reserves and the provisions, without their imposing;

- in case of shareholders, lack of the obligatory character for the additional value assessment resulting from share exchanges.

The income taxation for the nonresidents in Romania was regulated through the adaptation of the Fiscal Code to the requests mentioned in the Directive 77/799/CEE, that established the incomes liable to stand this type of taxation, the ways of determination, withholding and paying of the taxes, which is the concern of the income payers.
In Romania, the type of income taxation, corresponding to the savings got as interests, was regulated by the provisions stipulated in the Council's Directive no. $85 / 611 / \mathrm{CEE}$, approaching the way the payment is made and the beneficiary of the amount.

In order to prevent fraud and money laundering, steps were taken for identification and determination of the residential place for the real beneficiaries, by applying the provisions of the Directive no. 91/308/CEE. Thus, for the interest payment and tax application, the sum's beneficiary must carry out the provisions stipulated by the Directive no. $85 / 611 / \mathrm{CEE}$, that is to say the economic operator who makes the payment must inform the specialized authorities in the member-state where the sum's beneficiary have the domicile about the sums paid.

The taxation conditions for the interests and dues payments from Romania to a company registered in other EU memberstate was regulated by the implementation of the provisions of the Directive nr.2003/49/CE in the Romanian Fiscal Code.

An important part in the application of the EU directives is played by the information exchanges as far as the direct taxes are concerned, according to the agreement concerning the avoidance of double taxation, as implemented by the Directive no. 76/308/CEE about the mutual assistance regarding the recovery of particular tax liabilities, duties and other measures. The information provided to a member-state is considered state secret and it is to be used only for fiscal purposes.

Indirect taxation refers to the valueadded tax (VAT) as well as the excise duties and it is reflected in some complex EU legislation.

As for the value-added tax, the main source dealing with it remains the Directive no. 77/388/CEE - as well known as The Sixth Directive concerning VAT- including provisions about the persons and the taxable transactions as well as the exception or exemption for deliveries and services, about the location of taxable operations, the standard rates of taxation, the deductions and the appropriate mode of calculating them, 
about the persons in charge with the valueadded tax paying, etc., all of it meant as a gradual, transient process in all memberstates.

After the abrogation of fiscal boundaries, on the $1^{\text {st }}$ of January 1993 (by order of the Directive no. 91/680/CE), two other directives were promulgated, namely the Directives 92/77/CEE and 99/49/CE by means of which there were settled the rates of the value-added tax, and, subsequently, there were emitted ones more directives such as no. 2001/04/CE, no. 94/5/CE and no. 98/80/CE, which regulate the value-added taxation for particular goods (antiquities, collection items, gold coins with no numismatic value, etc.). The electronic commerce as well as the carrying out of public services (such as radioTV broadcasting and telecommunication) had as a consequence new regulations regarding the value-added tax, as they are mentioned in the Directives 99/55/CE, 2002/38/CE, 200/38/CE and 2002/792/CE.

Putting the community's acquis related to the value-added tax into practice implies recording of all legal entities operating acquisitions inside of the community, before they take place, and obeying the ceiling established by the corresponding regulations.

The allotment of the recording code on VAT-purpose is done according to the international standard ISO 3166 - alpha 2 . This code is to be reported to suppliers whenever intra-Community acquisitions of goods or services occur.

The intra-Community acquisition of goods means "getting the right of employing and exploiting - as a possessor - the tangible assets sent and transported to the destination mentioned by the buyer, by the seller or by some other person, at the buyer's or the seller's expense, to a member-state excepting the sender. To the category of intraCommunity acquisitions is also supposed to belong the overtaking - by the Romanian army, for personal use or for the use of the civilians within the armed forces - of goods they acquired in a member-state and whose acquisition was not subjected to any taxation rule in force in that particular state, when the importation of goods was not duty-free as the Fiscal Code stipulates.
It is essential to be established, within the intra-Community acquisitions, the exact location of the goods the moment their sending or transportation is over. Exception to the rule makes the case of a buyer reporting the seller a valid VAT identification number, a number that was emitted by a member-state, excepting the state hosting the acquisition, the place of the transaction being this time considered in the emitter-state of the very number.

If the intra-Community acquisition was subjected to taxation in another memberstate, the taxation basis in Romania is reduced accordingly.

The intra-Community acquisitions also include triangular transactions in a member-state, other than Romania, transactions done by the reselling buyer enlisted for TVA purposes in Romania; in this very case, the value-added tax is to be paid in that particular state, providing that the abovementioned reselling buyer could prove his having done the acquisition in order to be later delivered to that member-state where the beneficiary is registered and obliged to pay the tax. The obligation to register this operation is honoured by the reselling buyer recorded for TVA purposes in Romania.

The chargeable event influences the delivery of goods to the member-state hosting the acquisition, but the tax exigibility arises once the invoice is emitted for the whole equivalent value of goods, not later than 15 days in the month following the one in which the delivery took place.

The right of deduction corresponding to the intra-Community acquisitions is exercised by the taxable person, if the invoice or other documents demanded by the current legislation (that makes reference to the tax exigibility) are completed.

The Directive 92/12/CEE enlists the goods subjected to excise duties; according to the current legislation, the goods in question are: mineral oils, pure alcohol and alcoholic drinks and processed tobacco; moreover, the directive is applied to any member-state by means of the Treaty stipulating the founding of the Economic European Community.

The Romanian Fiscal Code includes a series of provisions concerning the 
appearance of shortcomings or straitened circumstances throughout the intraCommunity traffic, in suspensive regime, of the goods subjected to excise duty, stating the following:

- the real loss of goods is considered dutyfree; in keeping with the rules specific to the destination member-state, the excise duty is to be also applied to both registered and unregistered operators during the transport, in suspensive regime;

- in case of shortcomings and strained circumstances, during the transport, also involving the excise duty exigibility, the excise duty will be the concern of the physical or legal person from the country of origin that warranted the excise duty payment to the member-state where the shortcoming or the disorder appeared;

- if the goods liable to pay the excise duty do not reach the destination, and if the exact location for the inconveniences is impossible to find, they will be considered to have taken place in the member-state that delivered the goods, the supplier being the one charged for them.

If, within 4 months from the date of delivery, real evidence - meant to warrant the validity of the transaction or to find out the place where the shortcoming or the disorder appeared - is produced, then the supplier is exempt from the excise duty, and the payment is to be made in the memberstate where these inconveniences were determined.

The Romanian Fiscal Code stipulates the way in which the simplified document is made up, the way in which the payment and returning of the excise duty for the goods intended for consumption are done, in a member-state, only if they were paid on delivery.

The transactions between companies from the EU member-states might cause fiscal frauds resulting in the diminution of the tax liabilities owed to those states' budgets. For the triangular transactions, the frauds in question could be generated by means of:

missing traders that do not perform real activity and are managed by phoney persons. They could buy goods from suppliers throughout European Union, without paying the value-added tax, and they could resell them, TVA included, without transferring the funds;

buffers, with or without authentic activity, whose role is buying and selling large amounts of goods, with no value added. Their part consists of giving the transactions and the invoices the appearance of validity, thus making them credible and making the attempts to track down the frauds more complicated. Apparently, these companies do not commit frauds; international conduit companies, resembling the buffers, but unlike the latter - settled in a state different from the customer's location and encouraging the fraud in states where their customers belong. This type of companies does not commit frauds in the states where they have offices.

These means of tax evasioning are considered frauds of CARUSEL type and could be tracked down with the help of the information got via the Central Trade Connections Service and its Local Departments for international information exchange.

The role of the accounting appraisement is to determine the incongruities between the delivery papers' data, the bookkeeping and the fiscal situation of the companies operating intra-Community supply of goods or services, as requirements coming from the penal investigation and judicial bodies, on account of facts ascertained by the fiscal authorities.

\section{References:}

[1] Brezeanu P., Simon I., Celea S., Fiscalitate europeană, Editura Economică, Bucureşti 2005

[2] Florescu A.P.D., Coman P., Bălaşa G., Fiscalitatea în România, Editura All Beck, Bucureşti 2005

[3] ***, Codul fiscal aprobat prin Legea nr.571/2003, cu modificările şi completările ulterioare, Editura C.H.Beck, Bucureşti 2007 